\title{
A pilot workshop on Bryophytes at the National Herbarium (TAN) reveals the presence of seven additional species for Madagascar
}

\author{
Catherine Reeb, Rokiman Letsara, Roger Lala Andriamiarisoa, John C. Brinda, \\ Goudjo-Ameto Abalo-Loko, Elodie Boucheron-Dubuisson, Eberhard Fischer, \\ Nicholas G. Hodgetts, Elisabeth Lavocat-Bernard, Fara Naniarimino, Peter B. Phillipson, \\ Andrea Sass-Gyarmati \& Alain Vanderpoorten
}

\begin{abstract}
REEB, C., R. LETSARA, R.L. ANDRIAMIARISOA, J.C. BRINDA, G.-A. ABALO-LOKO, E. BOUCHERON-DUBUISSON, E. FISCHER, N.G. HODGETTS, E. LAVOCAT-BERNARD, F. NANIARIMINO, P.B. PHILLIPSON, A. SASS-GYARMATI \& A. VANDERPOORTEN (2019). A pilot workshop on Bryophytes at the Antananarivo Herbarium (TAN) revealed the presence of seven additional species for Madagascar. Candollea 74: 153-158. In English, English and French abstracts. DOI: http://dx.doi.org/10.15553/c2019v742a5

We present a contribution to the knowledge of the Malagasy bryoflora that results from a BRYOTAN workshop organized in September 2018 at the Antananarivo Herbarium (TAN) housed at the Parc Botanique et Zoologique de Tsimbazaza, Antananarivo, Madagascar, within the framework of the BRYOTAN project (Bryophytes of TAN). Seven taxa reported here as new for Madagascar were found among the specimens stored in TAN. These findings illustrate the interest of this sort of initiative, the potential richness of the unstudied material in herbaria, and the necessity of exploring regions that are bryologically poorly known within Madagascar.
\end{abstract}

\footnotetext{
Addresses of the authors:

CR, EBD: Institut de Systématique Evolution Biodiversité, Sorbonne Université,

Muséum National d'Histoire Naturelle, CNRS, EPHE, 57 rue Cuvier 75005 Paris, France. E-mail: catherine.reeb@mnhn.fr

RL, FN: Parc Botanique et Zoologique de Tsimbazaza, Antananarivo 101, Madagascar.

RLA: Missouri Botanical Garden, Lot vp 31, Ankadibevava Anjohy, Antananarivo, Madagascar.

GAAL: Université de Lomé, Faculté des Sciences, département de Botanique, Laboratoire de Botanique et Ecologie Végétale, BP 1515, Lomé-Togo.

JCB: Missouri Botanical Garden, 4344 Shaw Blvd., St. Louis, MO-63110, USA.

EF: Universität Koblenz - Landau, Institut für Integrierte Naturwissenschaften, Abteilung Biologie, Universitätsstraße 156070 Koblenz, Germany.

NGH: Botanical services Cuillin Views, 15 Earslish, Portree; Isle of Skye, IV51 9XL, UK.

ELB: Lotissement Moreau, 97128 Goyave, Guadeloupe.

PBP: Institut de Systématique Evolution Biodiversité, Sorbonne Université, Muséum National d'Histoire Naturelle, CNRS, EPHE,

57 rue Cuvier 75005 Paris, France and Missouri Botanical Garden, 4344 Shaw Blvd., St. Louis, MO-63110, USA.

ASG: Eszterházy Károly University, Department of Botany, Eger Postal Box 43, H-3301, Hungary.
} 


\section{Résumé}

REEB, C., R. LETSARA, R.L. ANDRIAMIARISOA, J.C. BRINDA, G.-A. ABALO-LOKO, E. BOUCHERON-DUBUISSON, E. FISCHER, N.G. HODGETTS, E. LAVOCAT-BERNARD, F. NANIARIMINO, P.B. PHILLIPSON, A. SASS-GYARMATI \& A. VANDERPOORTEN (2019). Un atelier pilote sur les Bryophytes à l'herbier d'Antananarivo (TAN) met en évidence la présence de 7 espèces supplémentaires à Madagascar. Candollea 74: 153-158. En anglais, résumés anglais et français. DOI: http://dx.doi.org/10.15553/c2019v742a5

Nous présentons une contribution à la connaissance de la bryoflore de Madagascar, suite à l'atelier BRYOTAN organisé en Septembre 2018 à l'herbier National malgache (TAN) situé dans le Parc Botanique et Zoologique de Tsimbazaza à Antananarivo dans le cadre du projet BRYOTAN (Bryophytes de TAN). Sept taxons non reportés jusqu’à présent pour Madagascar ont été décelés dans les spécimens stockés dans l'herbier, mettant en lumière l'intérêt de ce type d'initiative, la richesse des informations contenues dans les collections non encore traitées et la nécessité d'explorer des régions encore botaniquement mal connues de Madagascar.

\section{Keywords}

Bryophytes - Liverworts - Madagascar - Collections - Collaborative project 


\section{Introduction}

The island of Madagascar has long been recognized as a hotspot of biodiversity (Myers, 2003; Vences et al., 2009). Modern scientific study of Malagasy plants began in the $18^{\text {th }}$ century when the first explorers returned to Europe with their collections, which included a small number of bryophytes. These early bryophyte collections are present in various herbaria, notably in PC, G and BM. Despite further collecting efforts and taxonomic studies in the $19^{\text {th }}$ century (e.g. Bescherelle, 1880, 1881; Renaud \& Cardot, 1915) and more recent exploration of the island (e.g. Pócs \& GeissLer, 2002; Pócs \& VÁŇA, 2015; Ellis et al., 2017, 2018a, 2018b; REEB et al., 2018), documentation of Malagasy bryophytes is limited and the bryoflora remains poorly understood. This is true of both our taxonomic knowledge as well as our understanding of bryophyte evolution and ecology on the island. In the most recent checklist of Malagasy bryophytes (MarLine et al., 2012) 1,144 species are reported, including 751 mosses, 390 liverworts, and 3 hornworts. For comparison, the nearby island of La Réunion, 230 times smaller than Madagascar, is home to c. 800 species (AH-PENG et al., 2010), and in metropolitan France, an area roughly the same size but situated in the temperate zone where much lower alpha diversity would be expected, c. 1,300 species of bryophytes have been recordeed [https://inpn.mnhn.fr/]. These comparisons suggest that the Malagasy bryoflora is likely to be considerably larger than reflected by the data currently available. This is likely to be true despite the fact that careful study of bryophyte floras generally leads to many species being placed in synonymy (VANDER POORTEn et al., 2010). In the case of Madagascar, we expect that this will be more than offset by new discoveries for the island, including both range extensions of taxa known from elsewhere and very likely some species new to science, especially considering the exceptionally high levels of diversity and species-level endemism documented for other plant groups (CALlmander et al., 2011).

The BRYOTAN project (Bryophytes of TAN) [https:// www.bryotan.com] supervised by the Parc Botanique et Zoologique de Tsimbazaza (PBZT) is supported by GBIFBID. BRYOTAN forms part of the MADBRYO (Bryophytes of Madagascar) collaborative project, initiated by the Missouri Botanical Garden (St. Louis, USA) and the Muséum national d'Histoire naturelle (Paris, France) which aims to enhance our knowledge of Malagasy bryophytes [https://www.madbryo. org]. A primary goal of these two projects is to bridge the knowledge gaps in bryology by sharing specimens and taxonomic data that are scattered across multiple institutions and making them more accessible. An identification workshop was organized in the TAN herbarium of PBZT, Antananarivo from September 23rd to 29th 2018. Nine specialists worked for one week on the bryophyte specimens in TAN. These collections were often only identified to the family level and many others were unidentified even to this level. Here we present the results of this collaborative and stimulating exercise.

\section{Material and methods}

Historical collections from Madagascar from the $19^{\text {th }}$ century to the middle of the $20^{\text {th }}$ century are mostly held in European institutions (e.g. PC, G, BM). The TAN herbarium was created in 1950 and its bryophyte collection began with the specimens of Jean M. Bosser (coll. 1951-1970) and Georges A. Cremers (coll.1970-1975) (DorR, 1997). Botanists collecting in Madagascar and wishing to export specimens are required to deposit duplicates in TAN, therefore, many bryophyte specimens have accumulated there that are awaiting final determination to species and integration into the collections. As bryophyte collections often consist of a mixture of different species, due to their small size and because they often grow tangled together, it is also necessary to check identifications of duplicates stored in each institution. Prior to the BRYOTAN project, there was no dedicated herbarium space for the bryophyte collections in TAN. In the past, the curatorial team sorted and filed bryophyte specimens under the appropriate families and genera, based only on whatever taxonomic information was available on the label. Very often labels only have "field determinations" which are often misleading since bryophytes generally require microscopic examination for accurate identification and because they are frequently represented by mixed gatherings. During the workshop, after each specimen was determined by one of the specialists, all of the label data (including annotations) was captured into the Brahms database system (FILER, 2013). Data capture was performed by four master's students in bryology from the universities of Antananarivo and Mahajanga. When the digitization of the TAN collection has been completed, the data will be uploaded through the local GBIF node into the BryoTan dataset within GBIF [https://www.gbif.org/dataset/d06771c1-2276-49b881ba-f7be0887d0bd].

\section{Results}

Seven taxa were recorded for Madagascar for the first time, including one variety of liverwort and six moss species. Among the latter, two of the species belong to genera also recorded from Madagascar for the first time. Five of the new moss records originate from dry areas at low elevation; the others are from sub-humid areas at medium altitude (Fig. 1). The two new genera (Pseudocrossidium R.S. Williams and Luisierella Thér. \& P. de la Varde) belong to the Pottiaceae, a group that thrives in relatively harsh, dry environments suggesting that the bryophyte diversity of these habitats has not been sufficiently surveyed in Madagascar so far. 


\section{New records for Madagascar}

\section{Liverworts}

Plagiochila barteri var. valida (Steph.) Vanden Berghen in Bull. Jard. Bot. Natl. Belg. 51: 73. 1981. (Plagiochilaceae)

Notes - Plagiochila barteri is reported from Madagascar, Comoros, Mauritius and La Réunion, but the var. valida was so far only reported from La Réunion (Wigginton, 2018). It is easily distinguishable from P. barteri Mitt.var. barteri, which has previously been recorded from Madagascar (MARLINE et al., 2012), by the dorsal margin almost free of teeth (or with a few ones, < 6), and the bulging trigones between leaf cells (VANDEn Berghen, 1981).

Specimen examined. - Madagascar. Reg. Vatovavy-Fitovinany [Prov. Fianarantsoa]: Ranomafana parc, Along the $\mathrm{N}$ side of main road at the head of the big waterfalls on the Namorona River, dripping granitic cliffs surrounded by montane rainforest, $21^{\circ} 14^{\prime} 42^{\prime \prime} \mathrm{S} 47^{\circ} 23^{\prime} 50^{\prime \prime} \mathrm{E}, 1080-1150 \mathrm{~m}$, 29.VII.2004, S. E̊ T. Pócs 04126/AT (TAN, EGR).

\section{Mosses}

Calyptothecium acutifolium (Brid.) Broth. in Paris, Index Bryol. ed. 2, 1: 288.1904. (Pterobryaceae)

Notes - From dense humid evergreen forest from midelevations. Calyptothecium acutifolium was known from $\mathrm{La}$ Réunion in the Indian Ocean (O'SHEA, 2006).

Specimen examined. - Madagascar. Reg. Horombe [Prov. Toliara]: RS Kalambatritra, forêt d'Analamaro, 2328'40"S 46 23'38"E, 1330 m, 2.XI.2004, Andriamiarisoa 200 (MO,TAN).

Fissidens pallidinervis Mitt. in J. Linn. Soc., Bot. 12:592.1869. (Fissidentaceae)

Notes - Fissidens pallidinervis is widespread in Central and South America and is also recorded from Philippines and Australia. It is now known to be widespread in tropical Africa, with occurrences recorded in Burkina-Faso, Ghana, Central African Republic, Kenya, Tanzania, Uganda, Malawi, Zambia, Zimbabwe, La Réunion, Seychelles (Bruggeman-Nannenga, 2006, 2009). It grows on bark and rocks, but also on termite mounds (Seppelt \& STONe, 2016), in dense sub-humid evergreen forest at mid-elevation.

Specimen examined. - Madagascar. Reg. Horombe [Prov. Toliara]: RS Kalambatritra, forêt d'Analamaro, sur un termitier, terrestre, $23^{\circ} 28^{\prime} 14^{\prime \prime S}$ 462'ㄹ'”"E, 1330 m, 2.XI.2004, Andriamiarisoa 224 (MO, TAN).

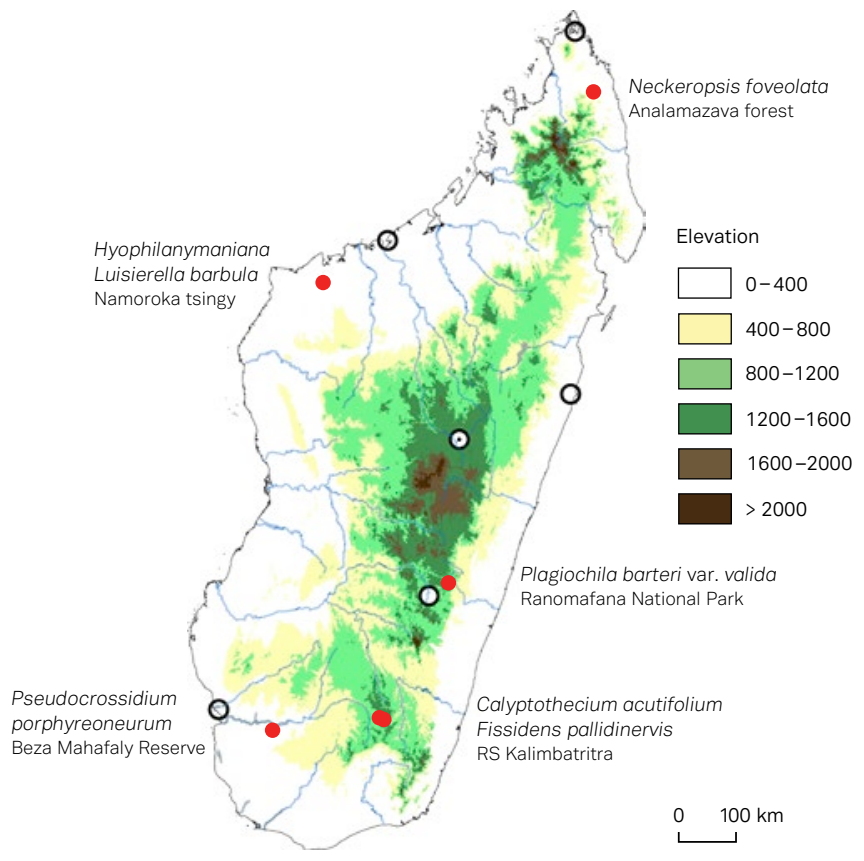

Fig. 1. - Distribution in Madagascar of the new reports from BRYOTAN workshop.

Hyophila nymaniana (M. Fleisch.) M. Menzel in Willdenowia 22: 198.1992. (Pottiaceae)

Notes - The distribution of Hyophila nymaniana is widespread but scattered in tropical regions. It is known from Central America (Costa Rica, Mexico), Africa (Central African Republic, Democratic Republic of Congo) and Southeast Asia (Java, Thailand). However, despite its wide distribution range, the species does not appear to be particularly common anywhere. In a worldwide revision of the genus Hyophila Brid., Sollman (2013) was able to recover 50 collections only.

Specimens examined. - Madagascar. Reg. Boeny [Prov. Mahajanga]: Tsingy de Namoroka National Park, anthropized area (rice fields, cultivation, cows) around Namoroka village, outside the cliff area, 16 $24^{\prime} 46^{\prime \prime} \mathrm{S} 45^{\circ} 18^{\prime} 25^{\prime \prime} \mathrm{E}$, 102 m, 28.X.2016, Reeb CR16M368 (PC [PC0773479], TAN); Andohifaly, dry forest mixed with savannah areas, with limestone cliffs up to 10-15 meters, 162''ㄹ"S 4517'04"E, 111 m, 28.X.2016, Reeb CR16M375 (PC [PC0773475], TAN).

Luisierella barbula (Schwägr.) Steere in Bryologist 48: 84. 1945. (Pottiaceae)

Notes - Luisierella barbula was described from Cuba and most collections come from the West Indies and adjacent areas in Mexico and the south-eastern United States, but it is also known from Japan, Southeast Asia, and scattered islands in the Indian Ocean (Seychelles: Aldabra; Mascarenes: Rodrigues). 
Its strong affinity for limestone substrates is a likely explanation for its distribution.

Specimen examined. - Madagascar. Reg. Boeny [Prov. Mahajanga]: Soalala, Tsingy de Namoroka National Park, dry forest with baobabs, $16^{\circ} 25^{\prime} 11^{\prime \prime S ~ 4516 ' 59 " E, ~} 96$ m, 28.X.2016, Reeb CR16M383 (PC [PC0773480], TAN).

Neckeropsis foveolata (Mitt.) Broth. in Engl. \& Prantl, Nat. Planzenfam. ed. 2, 11:188. 1925. (Neckeraceae)

Notes - Neckeropsis foveolata is found in Central and South America. In Africa, it mainly occurs in countries along the Gulf of Guinea, with occurrences documented in Cameroun, Ivory Coast, Equatorial Guinea, Ghana (Hodgetrs et al., 2016), Guinea (ELLIS et al., 2016), Liberia, Nigeria, and the Central African Republic. This is the first report of the species from an Indian Ocean island.

Specimen examined. - Madagascar. Reg. SAVA [Prov. Antsiranana]: Forêt humide d'Analamazava, $8 \mathrm{~km}$ du village d'Ankijabe, sur rocher, 13¹6'12"S 49³6'40"E, 617 m, 29.X.2005, Andriamiarisoa 506 (MO, TAN).

Pseudocrossidium porphyreoneurum (Müll. Hal.) R.H. Zander in Bull. Buffalo Soc. Nat. Sci. 32: 119.1993. (Pottiaceae)

Notes - Pseudocrossidium porphyreoneurum is relatively widespread in dry regions of sub-Saharan Africa (Botswana, Djibouti, Eritrea, Kenya, Malawi, Mozambique, Namibia, South Africa, Tanzania, Uganda, Zambia, Zimbabwe) and its occurrence in the semi-arid region of Madagascar is therefore not unexpected. There are many other species from similar habitats in continental Africa that might reasonably be expected to occur in Madagascar but have not yet been recorded. This may be the result of a collecting bias of bryologists towards humid forests but also because these areas are often less accessible. Furthermore, the species is generally represented by small and inconspicuous individuals.

Specimen examined. - Madagascar. Reg. Atsimo-Andrefana [Prov. Toliara]: Betioky-Atsimo; Beza Mahafaly Reserve, Parcelle No. 2, rocky hills near Betioky, 2341'S 44³6'E, 150 m, 20.V.1987, Phillipson 1832 (MO6491266, TAN).

\section{Discussion}

After one week of effort, we were able to report seven taxa that are new for Madagascar, showing the impact of our initiative. Even if no statistical analysis is feasible with these few data points, we observe (Fig. 1) that three of the new reports (including the two genera Luisierella and Pseudocrossidium) are from dry areas (Namoroka National Park, and Bezà Mahafaly Special Reserve respectively), while the others are from sub-humid forests of mid elevation. In the future we plan to organize additional identification workshops at other herbaria with significant collections of Malagasy bryophytes, especially as future collecting efforts are mobilised. For example, in PC, more than 14,000 new specimens of Malagasy mosses have been computerized since 2018 as part of a recently renewed databasing effort. These specimens are now much more accessible for identification or/and taxonomic revision.

\section{Acknowledgements}

We sincerely thank GBIF-BID and the European Union for funding the BRYOTAN project (AF2017-0174-NAC). We extend our warm thanks to Dr. Solo Rapanarivo, Head of the Botany Department at PBZT, Antananarivo for welcoming the workshop and for providing the space and materials necessary for its success. Thanks are also due to the Masters students Éliane Andriamihaja, Elysée Rakotoarison, Rita Rivoniriana and Miarisoa Solofonomenjanahary for their technical help during the workshop. We also thank the Muséum National d'histoire naturelle through the Institut de Systématique Evolution et Biodiversité, Pr. Guelly and Pr. Gliltho from Université de Lomé, Togo; and Missouri Botanical Garden, St. Louis for co-funding. We acknowledge the support of all the members of the MADBRYO steering committee who were not able to participate in the BRYOTAN workshop.

\section{References}

Ah-Peng, C., J. Bardat, P. Staménoff, T.A. Hedderson \& D. Strasberg (2010). Bryophytes de l'île de la Réunion: diversité, endémicité et conservation. Cryptogam. Bryol. 31: 241-270.

Bescherelle, É. (1880). Florule bryologique de la Réunion et des autres iles Austro-Africaines de l'Océan Indien. Ann. Sci. Nat., Bot. ser. 6, 9: 291-380.

Bescherelle, É. (1881). Florule bryologique de la Réunion et des autres iles Austro-Africaines de l'Océan Indien (deuxième partie). Ann. Sci. Nat., Bot. ser. 6, 10: 233-332.

Bruggeman-Nannenga, M.A. (2006). Bryophyte flora of Uganda. 6. Fissidentaceae (Part 2).J. Bryol. 28: 139-148.

Bruggeman-Nannenga, M.A. (2009). Notes on Fissidens VII-IX. J. Bryol. 31: 106-116.

Callmander, M.W., P.B. Phillipson, G.E. Schatz, S. Andriambololonera, M. Rabarimanarivo, N. Rakotonirina, J. Raharimampionona, C. Chatelain, L. Gautier \& P.P. Lowry II (2011). The endemic and non-endemic vascular flora of Madagascar updated. Plant Ecol. Evol. 144: 121-125.

Dor r, L.J. (1997). Plant Collectors in Madagascar and the Comoro Islands. Royal Botanic Gardens, Kew.

ELLIS, L.T. et al. (2016). New national and regional bryophyte records, 49. J. Bryol. 38: 327-34. 
ELLIS, L.T. et al. (2017). New national and regional bryophyte records, 53. J. Bryol. 39: 368-387.

ELlis, L.T. et al. (2018a). New national and regional bryophyte records, 55. J. Bryol. 40: 173-187.

ElLis, L.T. et al. (2018b). New national and regional bryophyte records, 56. J. Bryol. 40: 271-296.

Filer, D.L. (2013). BRAHMS 7 documentation [https://herbaria. plants.ox.ac.uk/bol/brahms].

Hodgetts, N.G., M.K. Essilfie, A. Adu-Gyamfi, E. Аком, J. Кumadoh \& J. Орокu (2016). Bryophytes of Atewa Forest, Eastern Region, Ghana. J. Bryol. 38: 211-222.

Marline, L., R.L. Andriamiarisoa, J. Bardat, M. Сhuah-Petiot, T.A.J. Hedderson, C. Reeb, D. Strasberg, N. Wilding \& C. Ah-Peng (2012). Checklist of the bryophytes of Madagascar. Cryptogam. Bryol. 33: 199-255.

Myers, N. (2003). Biodiversity hotspots revisited. BioScience 53: 91-97.

O'shea, B.J. (2006). Checklist of the mosses of sub-Saharan Africa (version 5,12/06). Tropical Bryology Research Report 6.

Pócs, T. \& P. Geissler (2002). The bryophytes collected in the Réserve Spéciale de Manongarivo, Madagascar. Boissiera 59: 41-76.

Pócs, T. \& J. VÁŇa (2015). East African bryophytes XXX. New liverwort and hornwort records. Acta Biol. Plant. Agri. 3: 3-21.

Reeb, C., L. Marline, L. Rabeau, A. Andriamanantena, R.L. Andriamiarisoa, H.L.T. Ranarijaona \& T. Pócs (2018). A survey of Marchantiales from Madagascar. Acta Biol. Plant. Agri. 6:3-72.

Renauld, F. \& J. Cardot (1915). Histoire naturelle des plantes mousses. In: Grandidie r, A. (ed.), Hist. Phys., Madagascar 39. Imprimerie Nationale, Paris.

Seppelt R.D. \& I.G. Stone (2016). Australian mosses online 70. Fissidentaceae. Australian Bryology Ressources Study. Canberra. Version 16 June 2016. [http://anbg.gov.au/abrs/Mosses_online/70_ V2_Fissidentaceae.html]

Sollman, P. (2013). A revision of the genus Hyophila Brid. (Musci, Pottiaceae) in Africa. Hoekstra Drukkerij \& Uitgeverij B.V., Sint Annaparochie.

Vanden Berghen, C. (1981). Le genre Plagiochila (Dum.) Dum. (Hepaticae) à Madagascar et aux Mascareignes, principalement d'après les récoltes de M. Onraedt. Bull. Jard. Bot. Belg. 51: 41-103.

Vanderpoorten, A., R.S. Gradstein, M.A. Carine \& N. Devos (2010). The ghosts of Gondwana and Laurasia in modern liverwort distributions. Biol. Rev. 85: 471-487.

Vences, M., K.C. Wollenberg, D.R. Vieites \& D.C. Lees (2009). Madagascar as a model region of species diversification. Trends Ecol. Evol. 24: 456-465.
Wigginton, M.J. (2018). Checklist and distribution of the liverworts and hornworts of sub-Saharan Africa, including the East African Islands (edition 4, 25 June 2018). Trop. Bryol. Res. Rep. 9. 